\title{
EFFECT OF INVESTOR SENTIMENT ON FUTURE RETURNS IN THE NIGERIAN STOCK MARKET
}

\author{
Udoka Bernard ALAJEKWU ${ }^{1}$, Michael Chukwumee OBIALOR ${ }^{2}$, \\ Cyprian Okey OKORO
}

${ }^{1}$ Ph.D. Student, Department of Banking and Finance, Nnamdi Azikiwe University, Anambra State, Nigeria, Tel.: +2347030997856, Email: blueben2010@yahoo.com

${ }^{2}$ Senior Lecturer, Department of Banking and Finance, Chukwuemeka Odumegwu Ojukwu University, Igbariam Campus, Anambra State, Nigeria, Tel.: +2348035080070, Email: bilors85@gmail.com

${ }^{3}$ Ph.D. Student, Department of Banking and Finance, Chukwuemeka Odumegwu Ojukwu University, Igbariam Campus, Anambra State, Nigeria, Tel.: +2348033403795, Email: cy.okoro2@yahoo.com

\begin{abstract}
The study investigated the effect of investor sentiment on future returns in the Nigerian stock market for a period covering the time from the first quarter of 2008 to fourth quarter of 2015. The OLS regression and granger causality techniques were employed for data analyses. The results showed that (1) investor sentiment has a significant positive effect on stock market returns even after control for fundamentals such as Industrial production index, consumer price index and Treasury bill rate; (2) there is a uni-directional causality that runs from change in investor sentiment ( $\triangle C C I)$ to stock market returns (Rm). Derived finding showed that the inclusion of fundamentals increased the explanatory power of investor sentiment from $3.96 \%$ to $33.05 \%$, though at both level, investor sentiment ( $\triangle C C I)$ has low explanatory power on stock market returns. The study posits existence of a dynamic relationship between investor sentiment and the behaviour of stock future returns in Nigeria such that higher sentiment concurrently leads to higher stock prices.
\end{abstract}

Keywords: investor sentiment; Nigerian stock market; stock returns; consumer confidence index; noise trading.

JEL Classification: $\mathrm{G}_{11}, \mathrm{M}_{12}$ 


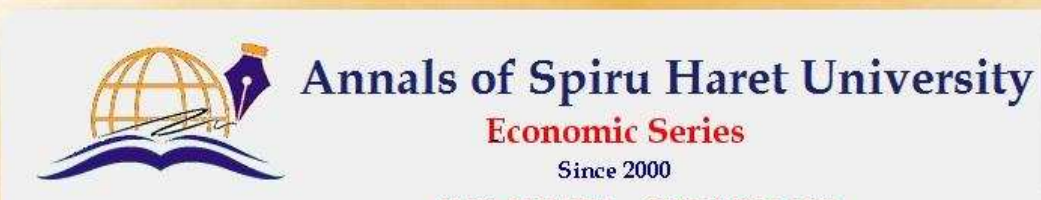

ISSN: 2393-1795 ISSN-L:2068-6900

Issue 2/2017

\section{Introduction}

\subsection{Background to the Study}

The term sentiment is associated with attitude, thought, or judgment prompted by feeling (Almansour, 2015). Li (2010) defines investor sentiment as "the general feeling, mood, belief or expectation of market performance". The term is not only used in psychology but also in the field of finance. Generally, sentiment is associated with the cognitive comparisons made by investors in their investment (Zweig, 1973). Investors can rely on cognitive factors as well as their experience in making investment decisions. Thus, sentiment is the investment decisions about asset prices that is not related with the economic and market fundamentals. Earlier researchers have seen sentiment as investors' biased expectations on asset values (Zweig, 1973); the noise in financial markets (Black, 1986); the component of investors' expectations about asset returns that are not justified by fundamentals (Lee, Shleifer \& Thaler, 1991). Further to this, Schmitz, Glaser and Weber (2006) define investor sentiment as the expectation of investors regarding the price of one or more financial assets that is not based on fundamental information. All these definitions point to the influence of non-fundamental variables on financial decision making. In a nutshell, investor sentiment is the bias in asset pricing which creates wrong value of financial assets, away from the equilibrium, as a result of use of physiological state rather than logical decisions based on fundamental.

Investor sentiment is a new concept in finance that has changed the belief about factors that affect asset pricing in financial markets. The traditional financial theorists have either ignored sentiment as a risk factor or assumed that prices are not affected by investor sentiment because their demands will be neutralized by the transactions of arbitrageurs and thus discounts the possible effects of sentimental investors (Wang, Li, \& Lin, 2009). This follows from the assumption that: firstly, financial markets are informationally efficient and secondly, market participants are rational. In an efficient market, absence of market friction guarantees price of marketable securities to be equal to their face value defined as the sum of present value of all expected cash flows (Gizelis \& Chowdhury, 2016). However the second assumption that individual investors behave rationally implies that they consider and rely on all available relevant information within their reach in all investment decision making. Rationality in financial markets is based on the hypothesis of rational expectations found in economic theory, which states that the predictions of economic agents regarding the future value of an asset are not systematically biased; that is, errors are not correlated. The classical financial theorists further argue that any additional factors introduced by noise traders will 104 


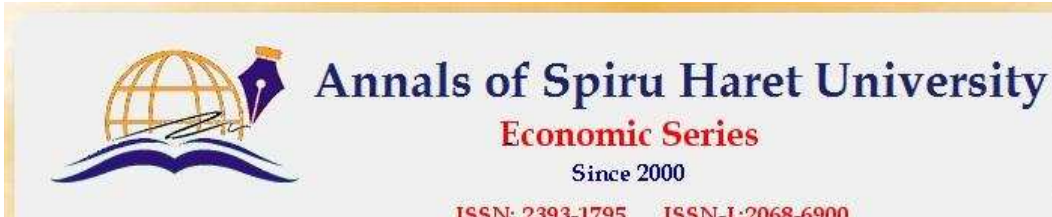

ISSN: 2393-1795 ISSN-I.2068-6900

Issue 2/2017

be quickly expelled from the market and with them the opportunities of making risk-free profits.

However, there have been reasons to believe that non-fundamental factors, such as sentiment, also influence asset pricing. History has shown that economic downturns, financial crises, political turmoil, and other social factors have caused the stock markets around the world to be unstable and highly volatile for investors (Guiso, Sapienza \& Zingales, 2008). A number of stock market events including the Great Crash of 1929, Tronics Boom and Go-Go years of the 1960s, The NiftyFifty bubble of the 1970s, Black Monday Crash of October 1987, the Dot.com bubble of the 1990s, 1997's East Asian financial crisis and the global financial crisis of 2008, are all cases that have not been explained by the classical finance theories (Almansour, 2015; Li, 2010). These events support the theoretical propositions of the Behavioural finance which posits that investor sentiment cannot be wished away in determining asset prices. They argue that sentiments will naturally affect asset prices because some investors are not completely rational; and arbitrage - which they describe as the transactions conducted by rational investors - is risky and therefore limited (Shleifer \& Summers, 1990).

However, investor sentiment caused by demand shocks of irrational traders could be correlated over time leading to a strong and persistent mispricing (Brown $\&$ Cliff, 2005). How long this stock mispricing last is determined by the activities of the rational investors (arbitrageurs) who will want to profit from the market disequilibrium caused by noise trading. Hughen and McDonald (2005) explained that the existence of significant arbitrage costs will impede the trading activity of the rational investors and limitation to arbitrage will exist as sentiment is crosssectionally correlated and the rational investors face the risk of continued movements away from fundamental values. The limits of arbitrage prevent rational traders to eliminate this influence on stock prices since it is unclear how long the buying or selling pressure from overly optimistic or pessimistic irrational traders will persist (Shleifer \& Vishny, 1997). However, every mispricing must eventually be corrected so that one should observe that high levels of investor optimism (pessimism) are on average followed by low (high) returns (Schmeling, 2009).

The aggregate stock market returns on the Nigerian stock market has witnessed consistent variations over time (see Figure). In the second quarter of 2008 , the market earns about $10.8 \%$ returns. The rate of stock returns from then till first quarter of 2009 nosedived as low as $9.8 \%$. The return has remained oscillatory from 2009 till 2015. This implies that investment in Nigeria can be risky. Theories and empirical studies have posited that perception of investors on share prices on 

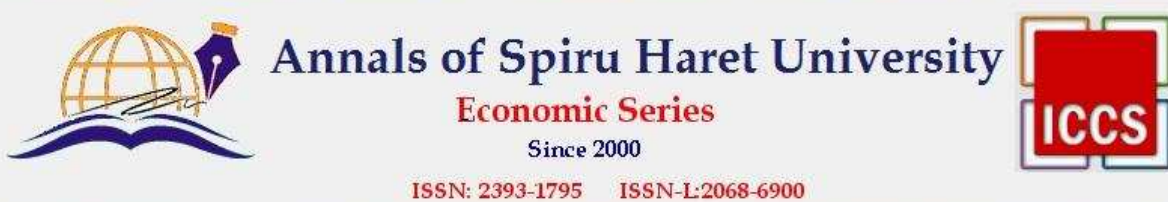

Issue $2 / 2017$

the market can be influenced by either rational fundamental factors or some set of irrational sentiments. Yet no study has been carried out to show evidence of the effect of investor sentiments on stock returns in Nigeria.

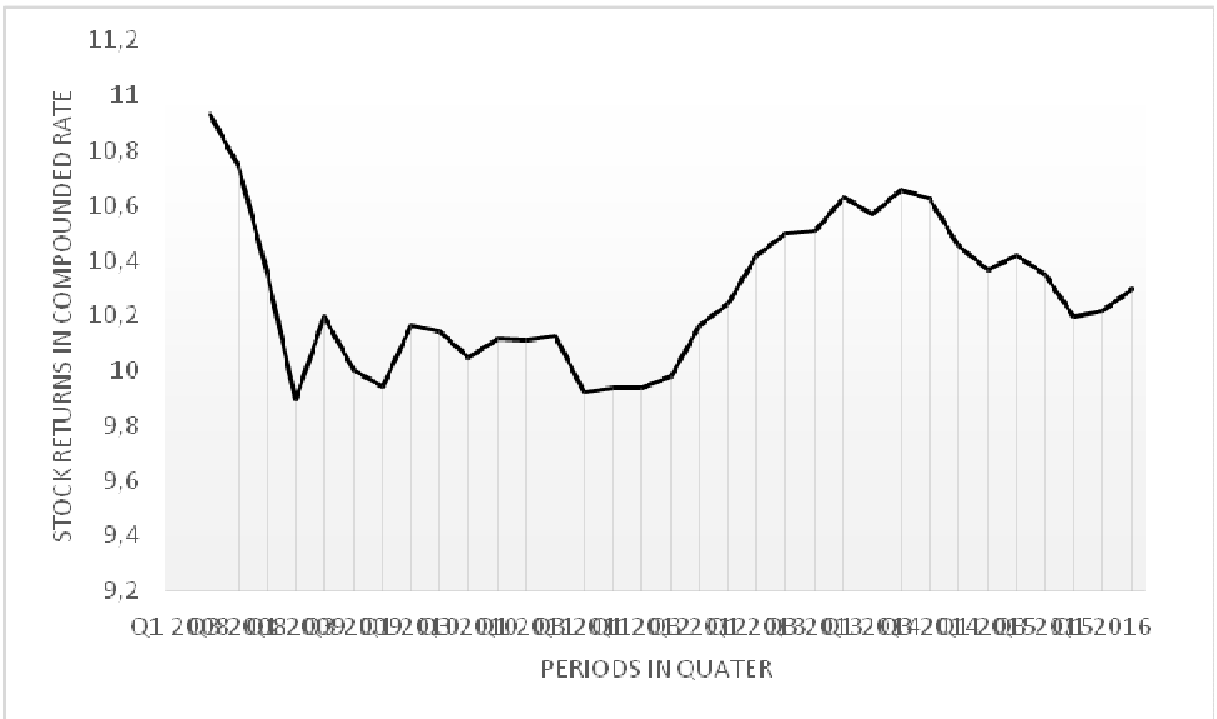

Figure no. 1. Aggregate stock market returns in Nigeria

\subsection{Statement of the Problem}

The conflict between the classical and behavioural finance theorists on the role of investor sentiment on asset prices is worth investigating in an undeveloped small size stock market like Nigeria. As developing and most emerging markets are dominated relatively more by individual investors that lack quality information and professional financial analysts' services, the performances of these markets are more likely to be influenced by the sentiment of general investors. Short selling usually is either not allowed or it is very shallow in many developing and emerging stock markets and this is for all practical purposes the case of the Nigerian market as well. Hence, as expected, the absence of the mechanism of short selling makes it difficult for smart investors to respond quickly to any new information in order to align mispriced stocks.

Despite the high possibility of presence of sentiment in the Nigeria capital market, there is hardly any known published papers dealing with the effect of 


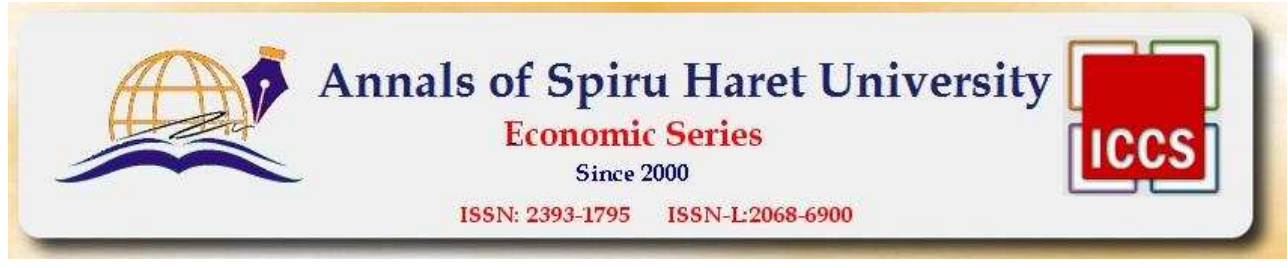

Issue $2 / 2017$

sentiment. Thus, this paper investigates the performance of the Nigerian stock market primarily from behavioural perspective by introducing sentiment factors in the empirical asset pricing models. The specific objectives include:

1. To examine the relationship between changes in investor sentiment and stock market returns.

2. To determine whether sentiment depends on previous returns or it is returns that depend on previous sentiment movements.

\subsection{Hypotheses}

Ho1: The relationship between sentiment and expected returns is significantly negative, even after controlling for fundamental factors.

Ho2: There is no causality between investor sentiment and future stock market returns.

\subsection{Scope of the Study}

The study was restricted to the use of only one sentiment indicator (Consumer Confidence Index - CCI) in measuring the effect of investor sentiment on stock returns. Since the computation of CCI available in CBN Statistical bulletin Survey started in 2008, the scope of this study covered the time frame of 2008 to 2016 using quarterly data.

\section{Literature Review}

\subsection{Theoretical Framework}

The theoretical framework of this study hinges on the divide between the traditional and behavioural finance theorists on the role of investor sentiment in asset pricing. The traditional finance theorists rule out the element of investor sentiment in asset pricing and states that rational investors make the market to become efficient such that all information that affect the prices of stock are known and accurately evaluated by the market participants. For instance, Capital Asset Pricing Model (CAPM) states that security prices will be at par with their fundamental value due to the presence of rational investors (Bathia \& Bredin, 2012). The latter efficient market hypothesis from Fama (1970) was based on the assumption of investor rationality, and posits that prices react only to information about changes in fundamental and considers noise as a non-fundamental factor that should not have any influence on asset pricing (Rehman \& Shahzad, 2016). Generally, Baker and Wurgler (2006) explained that traditional theorists fundamentally argue that competition among rational investors, who diversify to optimize the statistical properties of their 


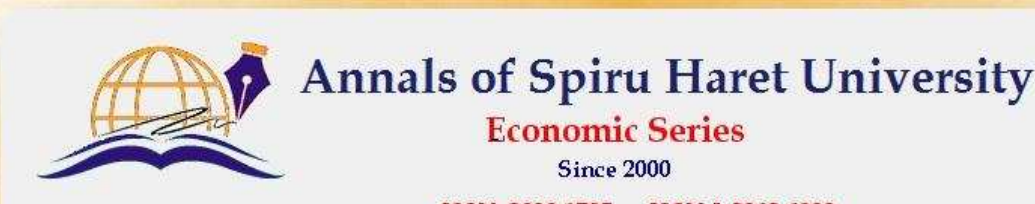

ISSN: 2393-1795 ISSN-L:2068-6900

Issue 2/2017

portfolios, will normally lead to an equilibrium in which prices equal the rationally discounted value of expected cash flows, and in which the cross-section of expected returns depends only on the cross-section of systematic risks. This is to say that the stock markets are efficient, the investors are rational in their behaviour and they utilize complete (possible) information for decision making, so the capital asset prices are adequate and reflect their intrinsic values without being effected by investor sentiment (Rehman \& Shahzad, 2016).This position connotes that sentiment has no role in asset pricing. The crux of this notion is that arbitrage activities of the rational investors will offset the mispricing caused by the irrational investors. Since the rational investors will always seek to exploit the profit opportunities in the market, their activities will counteract the asset mispricing and eliminate sentiment effects (Baker \& Wurgler, 2006; Stambaugh, Yu \& Yuan 2010; Bathia \& Bredin, 2012; Rahman, Shien \& Sadique, 2013).

On the contrary, the behavioural theorists posit that waves of sentiment effects (mispricing) will always subsist for significant periods of time (Schmeling, 2009). They contest the rationality hypothesis by assuming that investors are irrational, and that they are prone to exogenous sentiment waves. Investors may have incorrect stochastic expectations, either with overly pessimism or optimism, which results in an incorrect valuation of asset values, causing asset prices to deviate from their intrinsic values (Tran\& Nguyen, 2013)

According to Baker and Wurgler (2006), the two ingredients of sentimentbased mispricing are uninformed demand shock and a limit to arbitrage. In the first ingredient, Brown and Cliff (2005) contend that demand shocks of uninformed noise traders may be correlated over time to give rise to strong and persistent mispricing. This happens if sentiments results in herd behaviour leading to mass opinion and trading on wrong asset value. However, the second ingredient, the limits of arbitrage can deter informed traders from eliminating this situation (Shleifer \& Vishny, 1997) since it is a priori unclear how long buying or selling pressure from overly optimistic or pessimistic noise traders will persist. Further to this, Stambaugh, Yu and Yuan (2010) posit that sentiment effects might subsist if rational traders are not able to fully exploit the opportunities presented by the demand shocks of uninformed noise traders. The behaviourist however agreed that every sentiment effect (mispricing) must eventually be corrected so that one should observe that high levels of investor optimism are on average followed by low returns and vice versa (Tran \& Nguyen, 2013). 


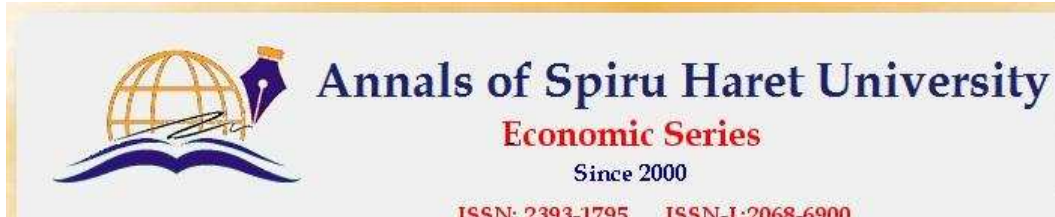

ISSN: 2393-1795 ISSN-I.2068-6900

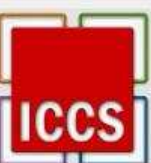

Issue $2 / 2017$

\subsection{Empirical Studies}

An ample of empirical studies has been conducted to provide evidence on the relationship between investor sentiment and stock returns. An earlier empirical study from Baker and Wurgler (2006) investigated how investor sentiment impacted on cross-section of stock returns by constructing an investor sentiment index based on the six measures including trading volume; dividend premium; close end fund discount; number of IPOs; average first-day returns on IPOs; and equity share in new issues. They developed a hard-to-value and difficult-to-arbitrage hypothesis in order to explain the cross-sectional effect of sentiment associated with firm characteristics, particularly for young, small size, unprofitable, growth, distressed, and non-dividendpaying stocks. Because of these stocks' lack of earnings history, tangible assets and collateral, they are more sensitive to subjective valuations and fluctuations in the propensity of speculation. Additionally, these stocks are likely to have lower liquidity and higher idiosyncratic risk, which means that they tend to be the riskiest and costliest to arbitrage. Therefore, these stocks are more profoundly affected by shifts in investor sentiment. It was however found that returns are relatively high (low) for small, young, growth and distressed stocks when beginning-of-period proxies for sentiment are low (high).

Schmitz, Glaser and Weber (2006) employed warrant transaction data set from a large discount broker to test whether individual investor sentiment is related to daily stock returns in Germany. The sentiment measured a data set of daily transactions of individual investors who had accounts at a big German online brokerage between January 1997 and April 2001. The sample was separated into a rising and a declining stock market. With the help of the spearman correlation, vector autoregressive models and Granger causality tests, the study found that a mutual influence exist in very short-run (one and two trading days) for sentiment on stock market returns. Further results showed that returns have a negative influence on sentiment, while the influence of sentiment on returns is positive for the next trading day. The influence of stock market returns on sentiment is strong and vice versa.

Schmeling (2009) investigated whether consumer confidence (a proxy for individual investor sentiment) affects expected stock returns internationally in 18 industrialized countries. The data covered a time series from January 1985 to December 2005. The study built a multiple regression model with consumer confidence as proxy for sentiment and macroeconomic variables as control to include annual CPI inflation, the annual percentage change in industrial production, the term spread, the dividend yield, and the detrended (6 months) short rate. The returns used 


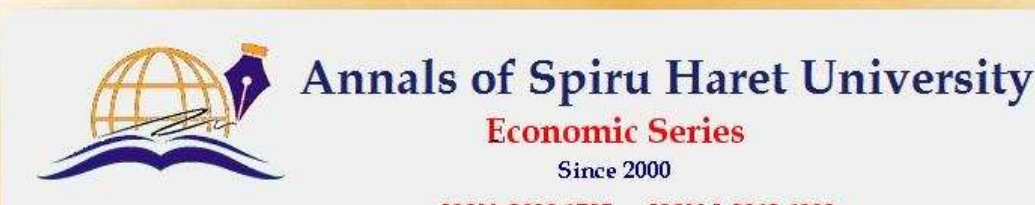

ISSN: 2393-1795 ISSN-L:2068-6900

Issue 2/2017

included aggregate market, value stocks and growth stocks forecasted with 1, 6, 12 and 24 months horizons. The Granger-Causality tests and Block exogeneity tests inferred there is two-way "causality" such that sentiment depends on previous returns and that returns depend on previous sentiment movements. Panel fixed-effects regression result showed that that sentiment negatively forecasts aggregate stock market returns on average across countries. This implies that high sentiment leads to lowers future stock returns and vice versa. This relation also holds for returns of value stocks, growth stocks, small stocks, and for different forecasting horizons. Again, the study employed a cross-sectional perspective and provides evidence that the impact of sentiment on stock returns is higher for countries which have less market integrity and which are culturally more prone to herd-like behaviour and overreaction.

With the help of two proxies for sentiments (Economic Sentiment Indicator and the Consumer Confidence), Fernandes, Gama and Vieira (2010) carried out a study that investigated the effect of investor sentiment on future aggregate stock market returns and industrial indices returns in Portugal within the period of September 1997 and April 2009. The study also examined whether a significant negative relationship exists between sentiment and expected returns after controlling for macroeconomic factors. The regression model analysis showed that sentiment had a negative impact on future market returns for forecast horizons of 1 to 12 months. In the industry analysis, they found that PSI Telecommunications was the index that showed a more similar behaviour to the aggregate market. For the other industry indices sentiment just had some predictive power on the future returns of the PSI Utilities and PSI Technology for forecasting horizons longer than 1 month. The study thus posits that stock market in Portugal is prone to the influence of sentiment.

Grigaliūnienė and Cibulskienè (2010) studied investor sentiment effect on stock returns at aggregate level and cross-sectionally in Scandinavian stock market using Sweden, Finland, Norway, and Denmark. The study employed Consumer Confidence Index (CCI) and Economic Sentiment Indicator (ESI) as measures of investor sentiment. The study found that high sentiment has a negative effect on future stock returns. Further results showed that the effect is more pronounced for hard-to-value and hard-to-arbitrage stock returns.

Bathia and Bredin (2012) studied the effect of investor sentiment on the stock market returns of the G7. The sentiment indicators employed included investor survey, equity fund flow, closed-end equity fund discount and equity put-call ratio covering a monthly data for the period January 1995-December 2007. The study 110 


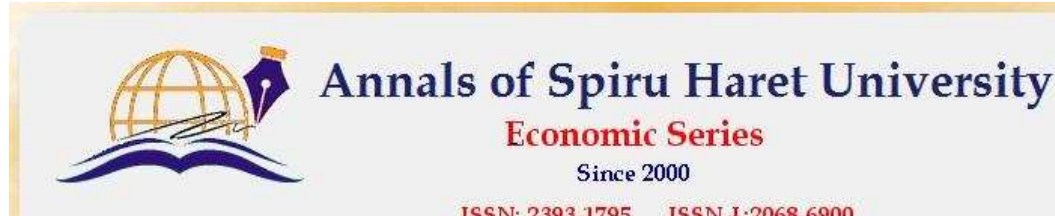

ISSN: 2393-1795 ISSN-I.2068-6900

Issue 2/2017

specifically investigated whether investor sentiment has a significant influence on value and growth stock returns as well as aggregate market returns. With the help of panel regression, the study found a negative relationship between investor sentiment and future returns. The study further showed that investor sentiment has inverse relationship with returns such that when investor sentiment is high (low), future returns are low (high). More so, the study showed that effect of survey sentiment on future returns slowly declines far above the one-month predicted time frame. The study also indicated that increases in concurrent equity fund flow causes price pressure on value stocks and the overall market, while the discount of closed-end equity fund was also found to proxy for investor sentiment, with a narrower discount being associated with an increase (decrease) in value (growth) stocks.

$\mathrm{Li}$ (2010) noted that the influence of investor sentiment cannot be ignored, as he acknowledged that investor sentiment induces uninformed demand shock especially in the face of high cost of arbitrage. Using multiple factors to construct a sentiment index, he examined the effect of investor sentiment on asset pricing mechanism of two stock exchanges in China. Six proxies were employed to form a composite sentiment index: the closed-end fund discount, A-share market turnover, the number of IPOs, the average first-day returns on IPOs, the number of new accounts opened, and consumer confidence index. By using multiple factors to construct a sentiment index, this study provides some evidence to show that if the sentiment at the beginning of a period is low, large stocks (growth stocks) tend to have relatively lower return than small stocks (value stocks), and vice versa. The study splitted the entire period into bull and bear periods, and found that the impact of investor sentiment in the bear periods is much more influential than in bull periods. Further results suggested that investors in the Chinese markets exhibit a significant learning effect. As the regression analyses show that the influence of the sentiment index is rarely significant since 2006, indicating that investor sentiment is not one of the major risk factors that should be accounted for in Chinese market in the recent times.

$\mathrm{Bu}$ and $\mathrm{Pi}$ (2014) examined the proxy variables of investor sentiment in Chinese stock market and constructed an investor sentiment index indirectly using data from January 2006 to December 2012, monthly. The study used a cross correlation analysis to examine lead-lag relationship between the proxy variables and HS300 index. The results show that net added accounts, SSE share turnover and closed-end fund discount are leading variables to stock market. The average first day return of IPOs and relative degree of active trading in equity market are 


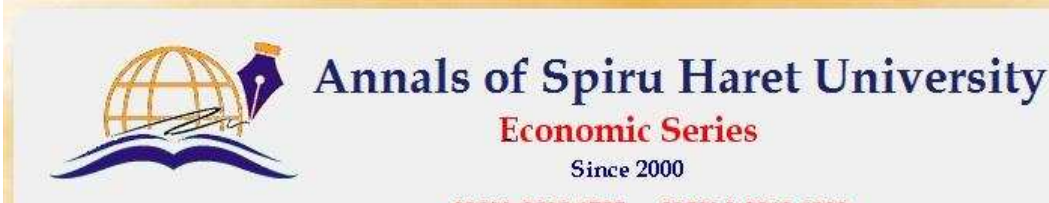

ISSN: 2393-1795 ISSN-L:2068-6900

\section{Issue $2 / 2017$}

contemporary variables, while number of IPOs is a lagging variable of stock market. Using the sentiment proxy variables with most possible leading order, and forward selection stepwise regression method, the empirical results on monthly stock returns reveal that three leading proxy variables can be used to form a sentiment index. The study thus posits that sentiment index has good predictive power of Chinese stock market.

With the help of a composite sentiment index constructed using eight proxies, Tran and Nguyen (2013) investigated the effects of investor sentiment on stock returns in the Norwegian and Vietnamese stock markets. The Principal Component Analysis was used to extract the first principal component of these 8 chosen proxies. 10 equally-weighted portfolios according to their characteristics of firm size, total risk, earnings-to-book ratio, dividend-to-book ratio, asset tangibility, $\mathrm{R} \& \mathrm{D}$ over assets, book-to-market ratio, and external finance over assets and sales growth were used. Through establishing portfolios of different types of stocks, we found that the sentiment effect on returns is stronger for stocks that are hard to value and hard to arbitrage, i.e. small, high volatility, non-dividend-paying, and value stocks. Sentiment negatively predicts these types of stocks' returns, i.e. when sentiment is low (high), future stock returns tend to be higher (lower). Particularly in Norway, when sentiment is high, subsequent returns are relatively low for small firms and unprofitable firms. In Vietnam, when sentiment is high, subsequent returns are relatively low for small firms and firms with highly volatile stock returns and viceversa. The results from a robustness test of the orthogonalized sentiment indices for Norway and Vietnam shows that the sentiment indices for Norway are sensitive to $V I X$ whereas the sentiment indices in Vietnam show no pattern. This implies that VIX plays an important role when constructing the sentiment index in a developed stock market, i.e. Norway, than in an emerging stock market, i.e. Vietnam. $C C I$ as a sentiment proxy can also forecast stock returns in Norway; however, its predictive power is not as strong as VIX.

Rahman, Shien, and Sadique (2013) investigated the impact of noise trader sentiment on the formation of expected returns and volatility in the context of the frontier stock market of Bangladesh. The study measured of sentiment shift using a modified trading index - a measure of relative strength of trading volume in relation to advancing stocks against that of declining stocks interpreted as the ratio of the average daily volume of declining stocks to the average daily volume of the advancing stocks. Returns were calculated as the logarithmic differences of prices times 100 while capitalization weighted returns on the portfolio of sample stocks is considered to represent the market return. The stock-level daily data over the period 112 

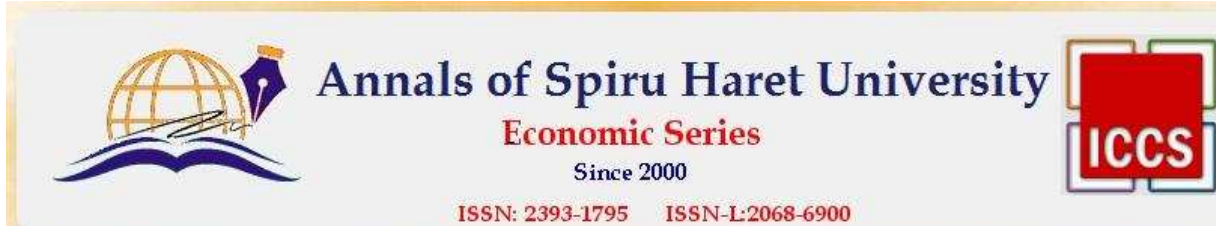

SSN: $2393-1795 \quad$ ISSN-I.2068-6900

Issue $2 / 2017$

from 1 Jan 2001 through 28 Dec 2012, and this was divided into two panel ranging from 2001 to 2006 and the other from 2007 to 2012. Empirical results based on a GARCH-in-mean framework show that shifts in investor sentiment are significantly positively correlated with excess market returns. In addition, the study found that the magnitude of bullish or bearish sentiment changes also exerts an indirect effect on expected returns through its asymmetric influence on the conditional volatility process.

In Romania, Oprea and Brad (2014) acknowledged that the attitude of individual investors is strongly correlated with their sentiment. They went further to posit that behaviour of investors on the stock market can generate important changes in price fluctuations. They then a study on the Bucharest Stock Exchange for a 10 year time period, starting from 2002 to 2011 to investigate the relationship between the evolution of stock market and the individual investor sentiment. The study used consumer confidence index as proxy for investor sentiment while stock returns was computed from the monthly all share index of the stock market. The result from a simple regression analyses showed that there is a positive correlation between changes in consumer confidence and stock market returns, demonstrating that individual investor sentiment affects stock prices. The study further found that the influence of individual investor sentiment seems to be quickly removed by the force of arbitrage with price adjustments realized in less than a month.

Employing the OLS regression technique, Huang, Jiang, Tu, and Zhou (2014) carried out a study to determine the model of investor sentiment index and relationship between investor sentiment and stock returns. Six sentiment measures were used: close-end fund discount rate, share turnover, number of IPOs, First-day returns of IPOs, Dividend premium, and Equity share in new issues, while the aggregate stock market return is computed as the excess return. By eliminating a common noise component in sentiment proxies, the new index has much greater predictive power than existing sentiment indices both in- and out-of-sample, and the predictability becomes both statistically and economically significant. In addition, it outperforms well recognized macroeconomic variables and can also predict crosssectional stock returns sorted by industry, size, value, and momentum.

Chowdhury, Sharmin, and Rahman (2014) introduced the behavioural factors in the empirical asset pricing models to investigate the effect of sentiments on Bangladesh stock market with data collected from Dhaka Stock Exchange. Returns were divided into market index, weighted large, medium and small stock portfolio returns. The study used the error term to capture the return that is not explained by macroeconomic variables, industrial production, inflation and interest rate. The 


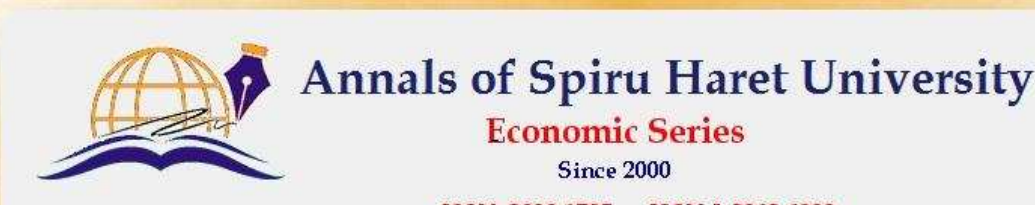

ISSN: 2393-1795 ISSN-L:2068-6900

Issue 2/2017

return was then regressed on sentiment variables (TRIN index, trade volume, number of IPOs per month, number of Beneficiary Owner account changes and moving average). The study found that TRIN and moving average significantly affect the residual market returns. Considering the impact of sentiment factors by firm size, the results show that the impact of TRIN and trade volume is strong for large and medium size firms. However, the effect of TRIN is either low or insignificant for small size firms, indicating less interest of investors for neglected stocks. Results also show that high sentiment leads to high return followed by negative correction in the next period. The study thus concluded that sentiment plays a big role in determining stock market performance indicating that the role of fundamentals is rather limited in the Bangladesh stock market.

Following the theory that a broad wave of sentiment will disproportionately affect stocks whose valuations are highly subjective and are difficult to arbitrage, Dalika and Seetharam (2015) investigated the effect of investor sentiment on the stock returns in the South African Market within the period covering 1999 and 2009. The study employed a composite index of investor sentiment as the linear combination of four indirect measures, namely, volatility premium, total volume of IPOs, average initial first day returns of IPOs and market turnover. However, the Johannesburg Securities Exchange (JSE) All Share Index was used as the proxy for stock market returns. The results indicate that investor sentiment has a strong impact on share returns in South Africa. When sentiment is low, subsequent returns are relatively high on smaller stocks, high volatility stocks, extreme growth stocks, and young stocks, with high sentiment reserving the patterns.

Almansour (2015) investigated the role of investor sentiment in asset pricing mechanism by focusing on Malaysian stock market and using data from January 2000 to December 2010; and further examines whether the influence of investor sentiment index on stock returns varies according to some characteristics of the firm. The technique of Principal Component Analysis (PCA) is used on market data to construct the investor sentiment index for Malaysian stock market. The market sentiment index derived from the sentiment proxies namely are Kuala Lumpur stock exchange share turnover, number of IPOs, first-day return on IPOs, dividend premium, equity share in new issues, price to earnings ratio for the market index, and the advance decline ratio. It was shown that Malaysian investor sentiment index could be measured by an equation of seven market variables. Using regression analysis and controlling for firm size, market-to-book ratio, financial leverage and growth opportunity, this index is shown to be able to predict Kuala Lumpur Composite Index (KLCI) returns in general. Further analyses which are 114 


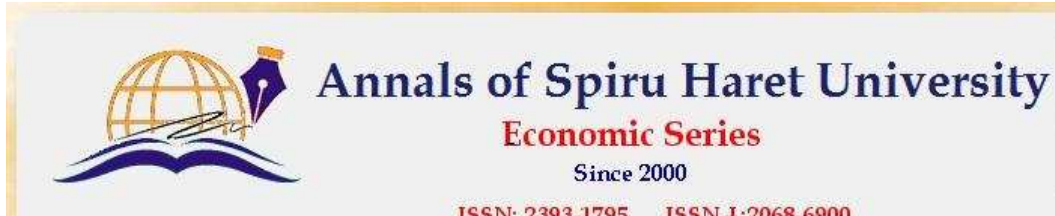

ISSN: 2393-1795 ISSN-I:2068-6900

Issue $2 / 2017$

based on portfolios of stocks formed based on size, risk and age show that the influence of the investor sentiment index on stock returns varies according to age and risk, but not size. However, after classifying the period of studies into before and after crisis periods, it is then shown that the significant relationship between the investor sentiment index and stock returns only takes place before the crisis period but not after the crisis period. The relationship between the index and stock returns is shown to differ according to firm age and risk after the crisis period but not before the crisis period. As a whole, the market sentiment is able to predict stock return in Malaysian equity market. The study thus posits that investor sentiment could be one of the major factors that should be accounted for in recent.

Rehman and Shahzad (2016) explored the time frequency relationship between investors' sentiments and industry specific returns in Karachi Stock Exchange of Pakistan. A sentiment index proxy was constructed using level and lag values of six indicators of investors' mood swing through Principle Component Analysis. The investors indicators were number of Initial Public Offerings (IPO), average $1^{\text {st }}$ day return on IPOs, Karachi Stock Exchange (KSE-100) Index average daily turnover, Equity/Debt ratio, closed end mutual fund discount, and dividend premiums. The data on investors' sentiments and nine major industry's returns was used from 2001 to 2011. Wavelet Coherency analysis reveal that investors' sentiments and industry returns are significantly related and are in phase (cyclical). An optimistic view of the investors regarding an industry's performance results in higher returns and pessimistic view results otherwise. The relationship is significant on $0 \sim 8$ and $32 \sim$ 64 months scale. Financial and energy crises play major role in the sentiment led industry's return.

Gizelis and Chowdhury (2016) examined the relationship between investor sentiment and stock market returns of firms listed in the Athens Stock Exchange using direct and an indirect sentiment proxies. The historical investor sentiment indicators compiled by the European Commission was used as the direct measurement of sentiment while the closed-end equity fund discount/premium was the indirect sentiment. Using monthly data for the period January 1995 to April 2014 the regression results indicate that investor sentiment weakly explains returns in Greece.

\subsection{Summary of Review and Gap in Literature}

The review of empirical studies on sentiment-return nexus showed that sentiment indicators significantly determine stock returns. These studies cut across developed and emerging economies in the world. A number of dimensions covered 


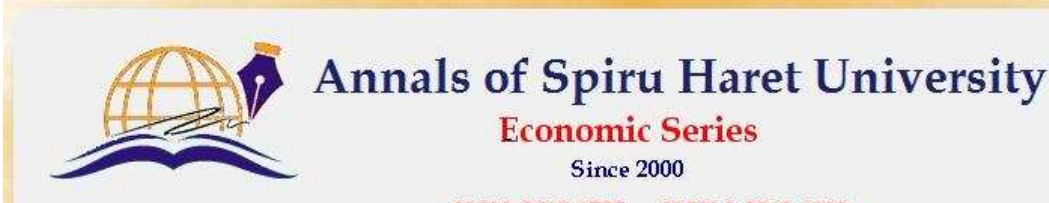

ISSN: 2393-1795 ISSN-L:2068-6900

Issue 2/2017

in existing studies are whether sentiment can affect stock returns; whether it affects returns of large firms as much as it affects those of small firms; the time periods within which sentiment effect can take to correct and return to equilibrium; and then the direction of causal effect of sentiment and returns. Among these issues, the widely accepted consensus findings have been that sentiment influences returns and that small firms suffer sentiment effects more than large firm returns. The issue on whether time frame for correcting stock mispricing is divergent across stock markets. Only one study exists on the direction of causal effect of sentiment return nexus. Among these objectives, the present study has undertaken to investigate existence of sentiment effect on stock returns in Nigeria, as well as determine the causal relationship between sentiment and stock returns.

However, the empirical studies in this area has come from developed countries of USA (Baker \& Wurgler, 2006), Germany (Schmitz, Glaser \& Weber, 2006); group of 18 industrialised nations (Schmeling, 2009), Greece (Gizelis \& Chowdhury, 2016), Norway and Vietnam (Tran \& Nguyen, 2013), Portugal (Fernandes, Gama \& Vieira, 2010), Romania (Oprea \& Brad, 2014), Sweden, Finland, Norway, and Denmark (Grigaliūnienė \& Cibulskienè, 2010) and the G7 nations (Bathia \& Bredin, 2012). The Asian world also has ample of extant literature that explains the sentiment-return nexus. Among these studies are works in China $(\mathrm{Li}, 2010 ; \mathrm{Bu} \& \mathrm{Pi}$, 2014; Huang, Jiang, Tu \& Zhou, 2014). Bangladesh (Rahman, Shien \& Sadique, 2013; Chowdhury,Sharmin \& Rahman, 2014), Malaysia(Almansour, 2015) and Pakistan (Rehman \& Shahzad, 2016); and African nation shared only one work from South Africa (Dalika \& Seetharam, 2015).Evidence has shown that there is no empirical evidence to explain sentiment-return nexus in Nigeria.

\section{Methodology}

In line with Gizelis and Chowdhury (2016), the market aggregates rather than individual stock data were used. Though, it is highly probable that sentiment will permeate across all stocks to the market level, we cannot rule out the possibility that the number of stocks positively affected by bullish sentiment is roughly the same as those that are negatively affected by bearish sentiment and thus they negate one another. However, as explained by Gizelis and Chowdhury (2016), the use of market aggregates is primarily imposed by pragmatic considerations stemming from the fact that most of the measures we examine are available for the entire market and not on a disaggregated level. The study collected secondary data from $\mathrm{CBN}$ documents to measure investor sentiments and stock market returns. 

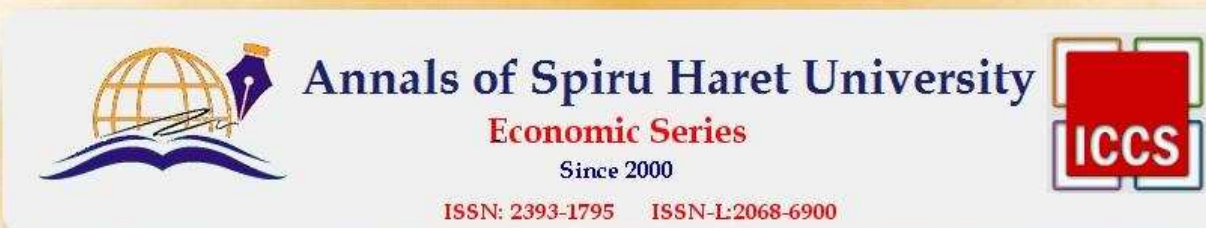

SSN: $2393-1795$ ISSN-I.2068-6900

Issue $2 / 2017$

Proxies for investor sentiment are the independent variables while stock market return is the dependent variable.

Stock market return $(\mathbf{R m})$ : Stock market return is the dependent variable of the study and is obtained from Central Bank of Nigeria Statistical bulletin, 2015. The data consisted of closing quarterly prices of all firms listed on the Nigerian Stock Exchange (NSE) for the period QTR1 2008 to QTR4 2015. The closing prices of the NSE All Share Index (ALSI) are specifically chosen as it is likely to be representative of the entire Nigerian securities market. The study followed the work of Oprea and Brad (2014) to transform the quarterly data of ALSI into continuously computed returns as:

$$
\mathrm{R}_{m l}=\operatorname{Ln}\left(\mathrm{P}_{\mathrm{t}}-\mathrm{P}_{\mathrm{t}-1}\right) / \mathrm{P}_{\mathrm{t}-1}
$$

Where: $R_{m t}$ represents quarterly market return for period $t ; P_{t}$ and $P_{t-1}$ denote market prices for period $t$ and period $t-1$ respectively and $L n$ denotes natural logarithm. The log transformation was employed in order to convert the data into continuously compounded rates. This practice is common rather than using discrete compounding (Simons \& Laryea, 2015).

Investor Sentiment Proxy: The study employed the Consumer Confidence Index to measure investor sentiment. This is obtained from investor survey reported in CBN Statistical Bulletin.The CBN analysts obtains the overall consumer confidence index as average of three (3) measures, namely, the outlook on macroeconomic conditions, family financial situation and family income (CBN, 2016).The consumer confidence index is the combined expectations and beliefs of investors on the fundamentals of the economy and markets. Lemmon and Portniaguina (2006), and Qiu and Welch (2005) argue that the consumer confidence index forms a direct measure of the general feeling of investors, and changes can measure the fluctuation of the stock returns, especially for small firms. This study used the inverse form of the CCI following the explanation of Oprea and Brad (2014) that CCI has only negative levels and as such have to be modified into its inverse form in order to reveal its impact on stock market return. Thus, we calculated the absolute value:

$$
\mathrm{CCI}_{-1}=\frac{1}{C \mathrm{CII}_{\mathrm{t}}}
$$



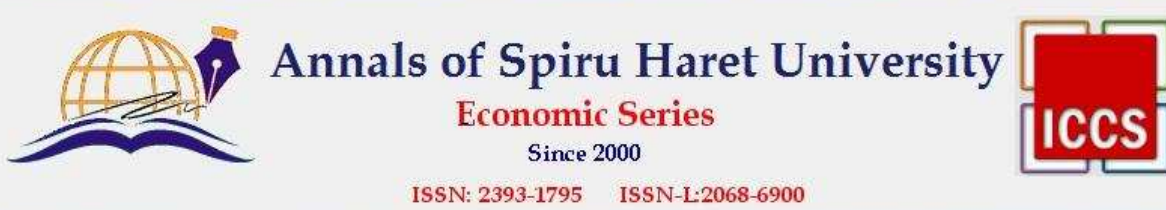

Issue 2/2017

Where $C C I_{t}$ is the level of consumer confidence index in quarter $t$. These mathematical tricks, according to Oprea and Brad (2014:21) have been used to sustain and to provide proper interpretation to the return - sentiment nexus. Also, the change of consumer confidence index was computed as follows:

$$
\Delta C C I_{-1}=\frac{\left.C C I_{-1} t-C C I_{-1 t-1}\right)}{C C I_{-1 t-1}}
$$

Where: $\triangle C C I t$ is the change of consumer confidence index in quarter $t$.

In line with previous studies, this study includes some macroeconomic indicators in order to capture how sentiment measures are related to overall economic activity. Following Gizelis and Chowdhury (2016), some of the key macroeconomic variables that are motivated by asset pricing theory are used including Industrial Production Index (IPI) as an indicator of economic activity, the Consumer Price Index (CPI) as a measure of inflation, and the treasury bill rate as a proxy for the risk-free nominal interest rate.

To examine whether investor sentiment predicts future aggregate stock market returns and industry indices returns in Nigeria, we follow Schmeling (2009) and Oprea and Brad (2014) to estimate the predictive regression equation of the form:

$$
R_{m t}=\beta_{0}+\beta_{1} \Delta \mathrm{CCI}_{-1 \mathrm{t}}+\varepsilon_{\mathrm{t}}
$$

Where: $R_{m t}$ represents quarterly market return of the aggregate stock market at time $t+1$ and $\Delta \mathrm{CCI}_{-1 \mathrm{t}}$ is the change in consumer confidence index in quarter $\mathrm{t}$ as proxy for lagged Nigeria investor sentiment. $\beta_{0}$ is a constant coefficient while $\beta_{1}$ defines the coefficient of the regression model 4 while $\varepsilon_{\mathrm{t}}$ is residual term.

Following the modelling adopted in Schmeling (2009) and Fernandes, Gama and Vieira (2010), the study added a set of macroeconomic factors as control variables and estimate the predictive regression equation of the form:

$$
R_{m t}=\beta_{0}+\beta_{1} \Delta \mathrm{CCI}_{-1 \mathrm{t}}+\lambda_{\mathrm{t}}+\varepsilon_{\mathrm{t}}
$$

The term $\lambda t$ is a macroeconomic factor matrix including $I P I, C P I$, and TBR being the quarterly inflation, interest rates and industrial production growth, respectively.

To address hypothesis two (Ho2), an endogenous model is developed as follows: 


\section{Annals of Spiru Haret University \\ Economic Series \\ Since 2000 \\ ISSN: 2393-1795 ISSN-L:2068-6900}

Issue $2 / 2017$

$$
\stackrel{\wedge}{R m}=\alpha_{0}+\alpha_{1} \stackrel{\wedge}{C} I_{-1 \mathrm{t}}+\mu_{\mathrm{t}}
$$

Where: $\mathrm{CCI}_{-1 \mathrm{t}}$ is the inverse value of the consumer confidence index in quarter $t$ as proxy for lagged Nigeria investor sentiment. $\alpha_{0}$ and $\alpha_{1}$ are the coefficients of the regression model. $\mu_{\mathrm{t}}$ is residual term.

A series of statistical analyses were carried out to address the objectives of the study. At first preliminary analyses were conducted to understand the nature of the variables employed in the study. These include the descriptive statistics involving mean, standard deviation, minimum, maximum and Jarque-Bera statistics, as well as multicolinearity test. The OLS regression technique was used to estimate the model for hypothesis one while granger causality techniques addressed hypothesis two of the study.

\section{Results and Discussion}

The descriptive statistics was used to test for the normality of the variables while multicolinearity tested with Variance Inflation Factor (VIF) tested for the reliability OF THE model.

Table no. 1. Descriptive statistics

\begin{tabular}{lccccc}
\hline & RM & $\Delta$ CCI & IPI & TBR & CPI \\
\hline Mean & 10.27 & -8.31 & 123.42 & 8.52 & 157.83 \\
Median & 10.22 & -8.40 & 125.25 & 9.00 & 156.90 \\
Maximum & 10.93 & 7.26 & 139.45 & 14.49 & 215.60 \\
Minimum & 9.90 & -24.63 & 90.80 & 1.04 & 104.90 \\
Std. Dev. & 0.26 & 8.05 & 15.46 & 3.57 & 32.13 \\
Skewness & 0.46 & -0.12 & -0.83 & -0.32 & 0.08 \\
Kurtosis & 2.46 & 2.76 & 2.76 & 2.27 & 1.90 \\
Jarque-Bera & 1.5991 & 0.1619 & 3.9854 & 1.3384 & 1.7391 \\
Probability & 0.4495 & 0.9222 & 0.1363 & 0.5121 & 0.4191 \\
& & & & & \\
Observations & 33 & 33 & 34 & 34 & 34 \\
\hline
\end{tabular}

Source: Data analysis from Eviews 8, 2017

The result of descriptive statistics on Table 1 showed that the mean for market return $(\mathrm{RM})$ indicates that $10.27 \mathrm{in} \log$ form is the average return of quoted firms in Nigeria between 2008 and 2016. The mean of change in consumer 


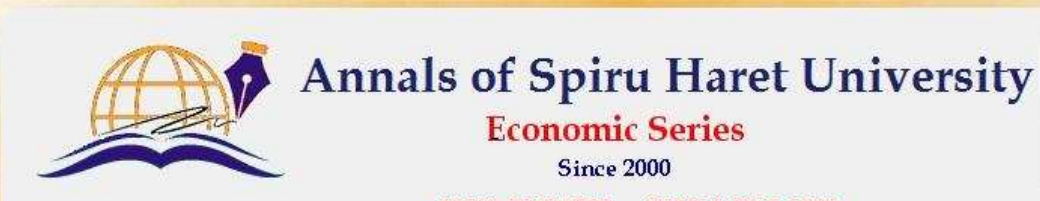

ISSN: 2393-1795 ISSN-L:2068-6900

\section{Issue $2 / 2017$}

confidence index is -8.31 which suggests that sentiment in Nigeria is on the negative. However, the mean for all the variables including RM, $\triangle \mathrm{CCI}$, IPI, TBR and CPI are higher than the respective standard deviations. This suggests possible stability in the distribution of the variables. The Jarque-Bera test was used to test for the normality of the variables. The Jarque-Bera test uses skewness and kurtosis measurements. The null hypothesis in this test is data follow normal distribution. Decision rule: Reject the null hypothesis, when p.value is less than 0.05 level of significance, otherwise, do not reject. Since the p.value of Jarque-Bera statistics is greater than 0.05 in all the variables (RM, $\triangle \mathrm{CCI}$, IPI, TBR and CPI) the study cannot reject the null hypothesis. Thus it concludes that all the variables RM, $\triangle \mathrm{CCI}$, IPI, TBR and CPI are normally distributed.

Further test of reliability is carried out to determine whether there is presence of multicolinearity in the model. This test becomes necessary since presence of multicolinearity in the data makes the OLS estimators imprecisely estimated (Ranjit, 2006). The Variance Inflation Factor (VIF) has been adopted to test for the presence of multicollinearity in the models. Decision Rule: "when the value of VIF is 10 and above, then the multicollinearity is problematic.

Table no. 2. Variance Inflation Factors for test of multicolinearity in the model

\begin{tabular}{ccc}
\hline \hline Variable & VIF & Remarks \\
\hline \hline CCCI & 1.107703 & No multicolinearity \\
IPI & 1.751225 & No multicolinearity \\
TBR & 1.388463 & No multicolinearity \\
CPI & 1.489564 & No multicolinearity \\
C & NA & \\
\hline \hline
\end{tabular}

Source: Data analysis from Eviews 8, 2017

The result on Table 2 is the VIF statistics of the explanatory variables of stock market returns ( $\triangle \mathrm{CCI}$, IPI, TBR and CPI). The results for all the variables are below 10. This indicates that inclusion of the independent variables as employed in the model does not bring about multicolinearity in the model. The study thus concludes that the model is reliable for examining the effect of sentiment on returns in Nigeria. 
Issue $2 / 2017$

Table no. 3. Model estimation of the effect of sentiment on returns Dependent Variable: RM

\begin{tabular}{|c|c|c|c|c|}
\hline \multirow[b]{2}{*}{ Variables } & \multicolumn{2}{|c|}{ Model 1} & \multicolumn{2}{|c|}{ Model 2} \\
\hline & Coefficient & $\begin{array}{l}\text { T-statistics } \\
\text { (P.value) }\end{array}$ & Coefficient & $\begin{array}{l}\text { T-statistics } \\
\text { (P.value) }\end{array}$ \\
\hline$\Delta \mathrm{CCI}$ & $0.0067 *$ & $\begin{array}{r}2.1319 \\
(0.0329) \\
\end{array}$ & $0.01525 * *$ & $\begin{array}{r}2.2897 \\
(0.0298) \\
\end{array}$ \\
\hline IPI & - & - & -0.0045 & $\begin{array}{r}-1.1749 \\
(0.21499)\end{array}$ \\
\hline TBR & - & - & 0.02745 & $\begin{array}{r}2.0164 \\
(0.0534) \\
\end{array}$ \\
\hline CPI & - & - & $0.0039 * *$ & $\begin{array}{r}2.1582 \\
(0.0396)\end{array}$ \\
\hline $\bar{C}$ & $10.3338 *$ & $\begin{array}{r}233.6966 \\
(0.0000)\end{array}$ & $10.1004 *$ & $\begin{array}{r}16.6137 \\
(0.000)\end{array}$ \\
\hline R-squared & 0.0396 & & 0.3305 & \\
\hline $\begin{array}{l}\text { F-statistic } \\
\text { (P.value) }\end{array}$ & $\begin{array}{r}7.2814 * * \\
(0.0329) \\
\end{array}$ & & $\begin{array}{r}3.456613 * * \\
(0.0204) \\
\end{array}$ & \\
\hline Durbin-Watson stat & 0.3790 & & 0.8014 & \\
\hline
\end{tabular}

*significant at $1 \%$; **significant at $\% \%$,

Source: Data analysis from Eviews 8, 2017

The result on Table 3 is used to address objective one of the study. The hypothesis tested is that: The relationship between sentiment and expected returns is significantly negative, even after controlling for fundamental factors. Two models are used to address this objective. The first model (1) regressed sentiment (CCI) on stock returns $(\mathrm{Rm})$. The second model (2) incorporated three economic variables: IPI (industrial production growth) as indicator of economic activities, CPI as indicator of inflationary trend and TBR as measure of risk free interest rate.

The result of Model 1 showed that a unit change in investor sentiment $(\triangle \mathrm{CCI})$ has positive effect on stock returns in Nigeria (coefficient $=0.0067$, t-statistics $=$ 2.1319 , p.value $=0.0329$ ). The result indicates that the higher the level of sentiment, the higher the expected returns from asset trading. Thus, positive sentiment leads to positive returns while negative sentiment brings about negative returns. The results showed that sentiment has significant effect on stock market returns on Nigeria.

The second model (2) incorporated control variables of fundamental factors. The results also showed that unit change in investor sentiment $(\triangle \mathrm{CCI})$ has positive effect on stock returns in Nigeria (coefficient $=01525$, t-statistics $=2.2897$, .value $=$ 
Issue 2/2017

0.0298). This suggests that sentiment has significant effect even when fundamental variables are factored in. The results showed that Industrial Production Index (IPI = 0.0045 ) has insignificant negative effect while Treasury bill rate as proxy for risk free interest rate (TBR $=0.02745$, not significant) and consumer price index as proxy for inflation (CPI $=0.0039$, significant) have positive relationship with stock market returns.

The coefficient of determination (R2) indicated that, in (model 1) $\Delta \mathrm{CCI}$ explains $3.96 \%$ while in model 2, it explains $33.05 \%$. The F-statistics indicated that the explanatory power remains statistically significant at both Model 1 and Model 2 . However, the value of $\mathrm{R} 2$ in each case is not large enough as it could not control at least half of the factors that explains stock returns in Nigeria. Thus it can be said that sentiment is not the major factor that determines stock market returns in Nigeria.

Table no. 4. Pairwise Granger Causality Tests of the causal relationship between sentiment and stock returns

\begin{tabular}{lcrll}
\hline Null Hypothesis: & Obs & F-Statistic & Prob. & Remark \\
\hline \hline$\Delta$ CCI does not Granger Cause RM & 31 & 3.90564 & 0.0329 Uni-directional causality \\
RM does not Granger Cause $\Delta$ CCI & & 0.90147 & 0.4183 from $\Delta$ CCI to RM \\
\hline \hline
\end{tabular}

The second objective aims to determine whether sentiment depends on previous returns or it is returns that depend on previous sentiment movements. This is tested using the granger causality analyses presented on Table 4. The result of the analysis test the two: "There is no causality between investor sentiment and future stock market returns". At 5\% level of significance, the study rejects the null hypothesis for " $\triangle \mathrm{CCI}$ does not Granger Cause RM" and concludes that change in investment sentiment $(\triangle \mathrm{CCI})$ granger causes stock market returns (RM). It however, did not reject the null hypothesis for RM does not Granger Cause $\Delta \mathrm{CCI}$.

\section{Conclusion and Recommendations}

\subsection{Conclusion}

This study has examined the effect of investor sentiment on stock market returns in Nigeria. The vast majority of previous studies on sentiment-return relationship have only examined the case of the developed American and European countries as well as Asian countries. 


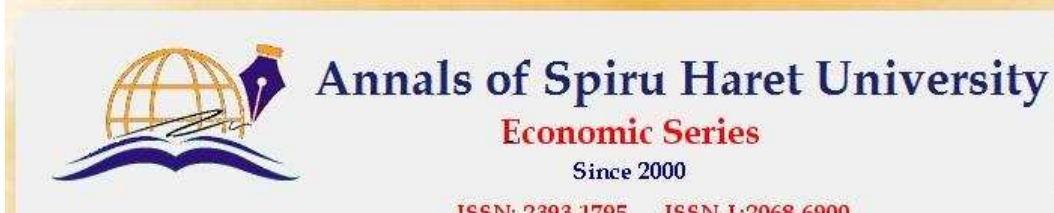

ISSN: 2393-1795 ISSN-I.2068-6900

Issue 2/2017

The present study has shown that investor sentiment has positive effect on the aggregate stock market returns in Nigeria. This implies that asset pricing can be influenced by changes in investor sentiments in Nigeria. The influence of sentiment on stock returns still hold even after the inclusion of market fundamentals such as industrial production index, inflation and risk free interest rate. The study thus concludes that there is a possible dynamic relationship between the investor sentiment and the behaviour of stock returns in Nigeria such that higher sentiment concurrently leads to higher stock prices. In the Nigerian stock market, sentiment is a source of market risk, which cannot be diversified away and hence it is priced. However, the study posits that sentiment is not a key variable for explaining changes in asset prices in Nigerian stock market.

\subsection{Recommendations}

A number of recommendations can be drawn from the findings of this study:

1. The results suggest several avenues for future work. In corporate finance, a better understanding of sentiment may shed light on patterns in security issuance and the supply of firm characteristics that seem to be conditionally relevant to share price. In asset pricing, the results suggest that descriptively accurate models of prices and expected returns need to incorporate a prominent role of investor sentiment.

2. Following the findings that sentiment is significant in determining stock returns, it is suggested that behavioural factors be considered in empirical asset pricing models for emerging stock markets.

\subsection{Limitations of the study}

One of the limitations of this study centres on the use of only one proxy as investor sentiment index. The reduced period of analysis, in this case due to the availability of data on some of the macroeconomic variables, is another limitation. The choice of these variables may represent yet another limitation. However, as Qiu and Welch (2006) posit that the consumer confidence index is a valid variable to obtain a proxy for investor sentiment, it becomes reasonable to accept that consumer confidence index alone (in the face of dearth of data to proxy sentiment index) can serve as a good measure for investor sentiment in a study of this nature. This is true following that some empirical studies have sufficiently employed only consumer confidence index and successfully examined the effect of investor sentiment on stock returns in other countries (Schmeling, 2009; Oprea \& Brad, 2014). 
Issue 2/2017

Author Contributions: Alajekwu Udoka Bernard, analyzed the data wrote the paper. Obialor M.C. provided the data for analyses and contributed in the review of related literature while C.O. Okoro did the content editing and fine-tuned the statement of problems and conclusion to the study.

Conflicts of Interest: The authors declare no conflicts of interest.

\section{References}

1. Almansour, B. Y. (2015). "The impact of market sentiment index on stock returns: An empirical investigation on Kuala Lumpur Stock Exchange", International Refereed Research Journal, VI(3), 1-28. Retrieved from http://www.researchersworld.com/ vol6/issue3/Paper_01.pdf.

2. Baker, M. \& Wurgler, J. (2006). "Investor sentiment and the cross-section of stock returns", Journal of Finance, 61(4), 1645-1680. Retrieved from http://people.stern.nyu.edu/jwurgler/papers/wurgler_baker_cross_section.pdf.

3. Baker, M. \& Wurgler, J. (2007). "Investor sentiment in the stock market", Journal of Economic Perspectives, 21(2), 129-151. Retrieved from http://people.stern.nyu.edu/ jwurgler/papers/wurgler_baker_investor_sentiment.pdf.

4. Bathia, D. \& Bredin, D. (2012). "An examination of investor sentiment effect on G7 stock market returns", Retrieved from http://www.ucd.ie/t4cms/Investor\% 20Sentiment_Bathia\%20\&\%20Bredin.pdf

5. Black, F. (1986). Noise. The Journal of Finance, 41(3), 529-543.

6. Brown, G. W. \& Cliff, M. T. (2005). "Investor sentiment and asset valuation", Journal of Business, 78(2), 405-440.

7. Bu, H. \& Pi, L. (2014). "Does investor sentiment predict stock returns? The evidence from Chinese stock market", J Syst Sci Complex, 27, 130-143. Retrieved from http://123.57. 41.99/jweb_xtkxyfzx/EN/article/downloadArticleFile.do?attachType= PDF\&id $=12234$.

8. CBN (2016). Consumer Expectations Survey Report: A Quarterly Publication. Second Quarter, 2016. Retrieved from https://www.cbn.gov.ng/out/2016/sd/2016\%20q2\%20 ces\%20report_final.pdf.

9. Chowdhury, S. S. H., Sharmin, R. \& Rahman, M. A. (2014). Effect of sentiment on the Bangladesh stock market returns. Retrieved from http://www.pmu.edu.sa/kcfinder/ upload/files/Dr\%20Shah_Chowdhury_EBES_Conference.pdf.

10. Dalika, N. \& Seetharam, Y. (2015). "Sentiment and returns: an analysis of investor sentiment in the South African market", Investment Management and Financial Innovations, 12(1), 267-276. Retrieved from http://businessperspectives.org/ journals_free/imfi/2015/imfi_en_2015_01\%20cont_2_Dalika.pdf. 
11. Fama, E. F. (1970). "Efficient capital markets: A review of theory and empirical work", Journal of Finance, 25, 383-417.

12. Fernandes, C., Gama, P. \& Vieira, E. (2010). Does sentiment matter for stock market returns? Evidence from a small European market at the industry level. XXXIV Enconro da ANPAD, 29th September, 2010. Retrieved from http://www.anpad.org.br/ admin/pdf/ fin1370.pdf.

13. Gizelis, D. \& Chowdhury, S. (2016). Investor Sentiment and Stock Returns: Evidence from the Athens Stock Exchange. Working Paper: MPRA Paper No. 71243. Retrieved from https://mpra.ub.uni-muenchen.de/71243/1/MPRA_paper_71243.pdf.

14. Grigaliūnienè, Z. \& Cibulskienè, D. (2010). "Investor sentiment effect on stock returns in Scandinavian stock market", Economics and Management, 15, 929-940. Retrieved from http://internet.ktu.lt/lt/mokslas/zurnalai/ekovad/15/1822-6515-2010-929.pdf.

15. Guiso, L., Sapienza, P., \& Zingales, L. (2008). "Trusting the Stock Market", The Journal of Finance, 63(6), 2557-2600.

16. Huang, D., Jiang, F., Tu, J. \& Zhou, G. (2014). "Investor sentiment aligned: A powerful predictor of stock returns", Review of Financial Studies, 28, (3), 791-837. Retrieved from http://ink.library.smu.edu.sg/cgi/viewcontent.cgi?article $=4774 \&$ context $=1 \mathrm{kcsb}$ research.

17. Hughen, J. \& McDonald, C. (2005). "Who are the noise traders?", The Journal of Financial Research, 28(2), 281-298.

18. Lee, C., Shliefer, A. \& Thaler, R. H. (1991). "Investor sentiment and the closed-end fund puzzle", The Journal of Finance, 46(1), 75-109.

19. Lemmon, M. \& Portniaguina, E. (2006). "Consumer confidence and asset prices: some empirical evidence", Review of Financial Studies, 19(4), 1499-1529

20. Li, Y. S. (2010). Does Investor Sentiment affect Cross-Sectional Stock Returns on the Chinese A-Share Market? A dissertation submitted to Auckland University of Technology in partial fulfilment of the requirements for the degree of Master of Business (MBus). Retrieved from http://aut.researchgateway.ac.nz/bitstream/ handle/10292/1184/LiY.pdf?sequence=3.

21. Oprea, D. S. \& Brad, L. (2014). "Investor Sentiment and Stock Returns: Evidence from Romania", International Journal of Academic Research in Accounting, Finance and Management Sciences, 4(2), 19-25. Retrieved from http://hrmars.com/hrmars_papers /Article_03_Investor_Sentiment_and_Stock_Returns1.pdf.

22. Qiu, L. X., \& Welch, I. (2006). "Investor Sentiment Measures”, Working paper, Brown University. Retrieved from http://papers.ssrn.com/sol3/papers.cfm?abstract_ $\mathrm{id}=589641$

23. Rahman, M. A., Shien, L. K. \& Sadique, M. S. (2013). "Swings in sentiment and stock returns: Evidence from a frontier market", International Journal of Trade, Economics and Finance, 4(6), 347-352. Retrieved from http://www.ijtef.org/papers/315-B00059.pdf. 


\section{Issue 2/2017}

24. Ranjit (2006). Multicollinearity: causes, effects and remedies. Retrieved from http://www.iasri.res.in/seminar/AS-299/ebooks\%5C2005-2006\%5CMsc\%5Ctrim 2\%5C3.\%20Multicollinearity-\%20Causes,Effects\%20and\%20Remedies-Ranjit.pdf.

25. Rehman, M. U. \& Shahzad, S. J. H. (2016). "Investors' sentiments and industry returns: Wavelet analysis through Squared Coherency Approach", ACRN Oxford Journal of Finance and Risk Perspectives, 5(1), 148-159. Retrieved from http://www.acrnjournals.eu/resources/jofrp0501g.pdf.

26. Schmeling, M. (2009). "Investor sentiment and stock returns: Some international evidence", Journal of Empirical Finance, 16, 394-408. Retrieved from http:// diskussionspapiere.wiwi.uni-hannover.de/pdf_bib/dp-407.pdf.

27. Schmitz, P. Glaser, M. \& Weber, M. (2006). Individual investor sentiment and stock returns - what do we learn from warrant traders? http://www.efmaefm.org/ OEFMSYMPOSIUM/2006/papers/86-EFM\%20-\%20Schmitz\%20Philipp\%20$\% 20$ Individual\%20Investor\%20Sentiment\%20.pdf

28. Shleifer, A. \& Summers, L.H. (1990). "The noise trader approach to finance", Journal of Economic Perspectives, 4(2), 19-33.

29. Shleifer, A. \& Vishny, R. (1997). "The limits of arbitrage", The Journal of Finance, 52(1), 35-55.

30. Simons, D. \& Laryea, S. A. (2015). Testing the efficiency of selected African stock markets. Retrieved from http://economics.ca/2004/papers/0056.pdf

31. Stambaugh, R. F., Yu, J., \& Yuan, Y. (2010). The Short of it: Investor Sentiment and Anomalies: National Bureau of Economic Research.

32. Tran, T. U. T \&Nguyen, N. Y. T. (2013). The effect of investor sentiment on stock returns in Norway and Vietnam. Being a study submitted for Master of Science in Business and Economics program at BI Norwegian Business School. Retrieved from https://brage.bibsys.no/xmlui/bitstream/handle/11250/95109/Oppgave9.pdf? sequence $=1$

33. Wang, Y. M., Li, A., \& Lin, F. (2009). "The Impact of Investor Sentiment on the Futures Market: Evidence from the Taiwan Futures Exchange", Journal of Finance and Economics, 28, 134-151.

34.Zweig, M. E. (1973). "An investor expectations stock price predictive model using closed-end fund premiums", The Journal of Finance, 28(1), 67-78. 